\title{
KONDISI EKOLOGI DAN NILAI MANFAAT HUTAN MANGROVE DI DESA LANSA, KECAMATAN WORI, KABUPATEN MINAHASA UTARA
}

\author{
(Conditions Of Ecology and Mangrove Forest Benefits In Lansa Village, \\ Wori District, North Minahasa District)
}

\author{
Roberto Takarendehang ${ }^{1 \star}$, Calvyn F.A. Sondak ${ }^{1}$, Erly Kaligis ${ }^{1}$, \\ Deslie Kumampung ${ }^{1}$, Indri S. Manembu ${ }^{1}$, Unstain N.W.J. Rembet ${ }^{2}$ \\ ${ }^{1)}$ Program Studi Ilmu Kelautan Fakultas Perikanan dan IImu Kelautan, \\ Universitas Sam Ratulangi, Manado. \\ ${ }^{2)}$ Program Studi Manajemen Sumber Daya Perairan Fakultas Perikanan dan Ilmu Kelautan, \\ Universitas Sam Ratulangi, Manado. \\ "E-mail: robertotakarendehang@yahoo.co.id
}

\begin{abstract}
Mangrove forests are biological natural resources that have a variety of potentials that benefit human life both directly and indirectly and can be felt, both by people who live near the mangrove forest area and people who live far from the mangrove forest area. Mangrove forests also have high economic and ecological values but are very vulnerable to damage if they are not wise in maintaining, preserving and managing them. Collecting data to find out the benefits of mangrove forests for the people of Lansa Village is done by survey methods in the form of direct interviews with the community using the ecosystem.

Data collection on the ecological conditions of mangroves is carried out by making plots. The number of plots in this study are nine plots. Each plot has a size of $10 \times 10 \mathrm{~m}$. Retrieval of data in this study are: the type of mangrove, the relative density of species, the relative frequency of types, the closure of relative types, and the index of important values. Based on the results of interviews with the community regarding mangrove forests are mangrove regulation services, mangrove provisioning services and mangrove cultural services. The most extensive assessment of the use of mangrove forests is the construction of embankments of Rp. 2,583,300,000 and followed by utilization of fish Rp. 1,521,429,000 and then utilization of fuel wood Rp259.200.000. With the total economic value of the mangrove forest in Lansa Village, it is Rp.4,363,929,000 per year.
\end{abstract}

Keywords : Ecological Conditions, Benefits Of Mangrove Forests, Lansa Village.

Hutan mangrove merupakan sumberdaya alam hayati yang mempunyai berbagai keragaman potensi yang memberikan manfaat bagi kehidupan manusia baik yang secara langsung maupun tidak langsung dan bisa dirasakan, baik oleh masyarakat yang tinggal di dekat kawasan hutan mangrove maupun masyarakat yang tinggal jauh dari kawasan hutan mangrove. Hutan mangrove juga memiliki nilai ekonomis dan ekologis yang tinggi akan tetapi sangat rentan terhadap kerusakan apabila kurang bijaksananya dalam mempertahankan, melestarikan dan mengelolahnya. Pengambilan data untuk mengetahui manfaat hutan mangrove bagi masyarakat Desa Lansa dilakukan dengan metode survei dalam bentuk wawancara langsung dengan masyarakat pengguna ekosistem.

Untuk pengambilan data kondisi ekologi mangrove dilakukan dengan pembuatan plot. Jumlah plot dalam penelitian ini adalah sembilan plot. Setiap plot memiliki ukuran $10 \times 10 \mathrm{~m}$. Pengambilan data dalam penelitian ini adalah: jenis mangrove, kerapatan relatif jenis, frekwensi relatif jenis, penutupan relatif jenis, dan indeks nilai penting. Berdasarkan hasil wawancara dengan masyarakat mengenai hutan mangrove adalah mangrove regulation service, mangrove provisioning service dan mangrove cultural services. Penilaian pemanfaatan hutan mangrove yang paling banyak yaitu pembangunan tanggul $\mathrm{Rp}$ 2.583.300.000 dan diikuti oleh pemanfaatan ikan Rp 1.521.429.000 dan kemudian pemanfaatan kayu bakar Rp 259.200.000. Dengan jumlah total nilai ekonomi hutan mangrove Desa Lansa adalah Rp 4.363.929.000 per tahun.

Kata kunci: Kondisi Ekologi, Manfaat Hutan Mangrove, Desa Lansa. 


\section{PENDAHULUAN}

Sumber daya alam mempunyai peran penting dalam kelangsungan hidup manusia. Pengelolaan terhadap sumber daya alam harus sangat bijaksana. Karena diperlukan waktu yang cukup lama untuk bisa memulihkan kembali apa bila telah terjadi kerusakan atau kepunahan. Pengelolaan secara bijaksana yaitu pemanfaatan dan pengelolaan sumberdaya yang optimal dan berwawasan lingkungan agar sumberdaya alam yang ada tetap lestari.

Hutan mangrove merupakan salah satu sumberdaya alam wilayah pesisir yang mempunyai peranan penting ditinjau dari sudut sosial, ekonomi, dan ekologis. Fungsi utama sebagai penyeimbang ekosistem dan penyedia berbagai kebutuhan hidup bagi manusia dan makhluk hidup lainnya. Sumberdaya hutan mangrove, selain dikenal memiliki potensi ekonomi sebagai penyedia sumberdaya kayu, penangkapan ikan, kepiting dan lain - lain, juga berfungsi untuk menahan gelombang laut dan intrusi air laut ke arah darat (Benu $d k k$., 2011). Fungsi lainnya adalah sebagai sumber penghasilan masyarakat pesisir yang dapat dikembangkan sebagai wisata, pertanian atau pertambakan, dan lain sebagainya.

Jasa ekosistem adalah barang atau jasa yang disediakan oleh ekosistem untuk manusia dan menjadi dasar untuk penilaian suatu ekosistem (Hein et, al.,2006). Ketersedian jasa ekosistem sering bervariasi dengan berjalannya waktu dan ketersediannya secara aktual dan potensial di masa depan harus menjadi bagian dari penilaian.

Hutan mangrove yang berada di Desa Lansa memiliki luas kurang lebih 156,10 ha dan memiliki kondisi ekologi yang cukup baik. Manfaat yang diberikan oleh ekosistem hutan mangrove kepada masyarakat antara lain sebagai pelindung pantai, kayu bakar, tempat penangkapan ikan, bahan bangunan rekreasi.

Menyadari pentingnya ekologi dan nilai manfaat ekosistem hutan mangrove ini, diperlukan penilaian untuk mengetahui seberapa besar nilai dan manfaat ekosistem mangrove di Desa Lansa. Dan hasilnya diharapkan bisa dijadikan bahan informasi bagi masyarakat maupun pemerintah dalam pengambilan keputusan dan kebijakan, serta pemanfaatan yang tepat untuk ekosistem hutan mangrove yang ada di Desa Lansa, Kecematan Wori, Kabupaten Minahasa Utara.

\section{METODE PELAKSANAAN}

\section{Waktu dan Tempat}

Penelitian ini dilakukan di Desa Lansa, Kecamatan Wori, Kabupaten Minahasa Utara. Waktu pelaksanaan penelitian dilaksanakan mulai bulan Februari sampai dengan Mei 2018.

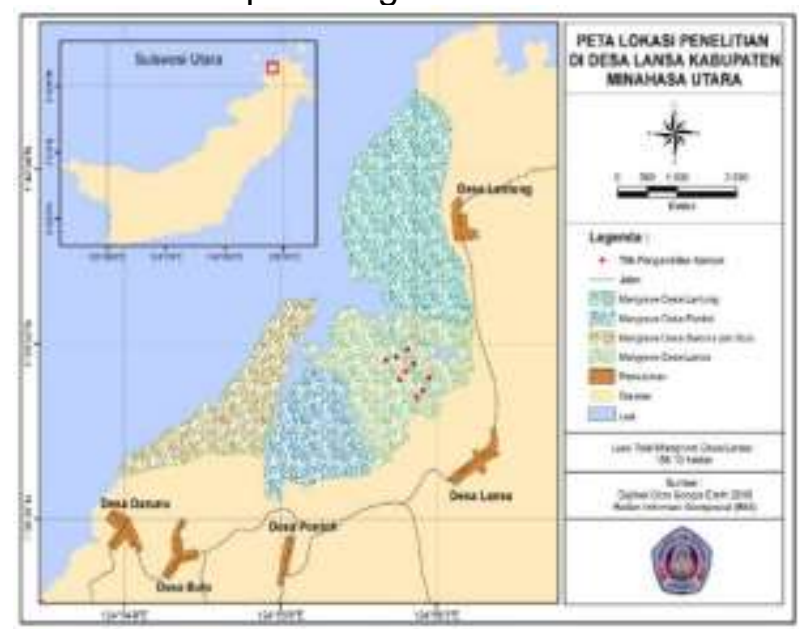

Gambar 1. Lokasi Penelitian.

\section{Alat dan Bahan}

Adapun alat dan bahan yang digunakan dalam penelitian ini yaitu:

Tabel 1. Alat dan bahan penelitian.

\begin{tabular}{|c|c|c|}
\hline No & Alat dan bahan & Kegunaan \\
\hline 1 & TaliPlastik & Membuat plot \\
\hline 2 & Meter Roll & Mengukurtali \\
\hline 3 & Meteran & Mengukur diameter pohon \\
\hline 4 & $\begin{array}{l}\text { Data Sheet } \\
\text { GPS (Global }\end{array}$ & Menulissetiap data yang didapat \\
\hline 5 & $\begin{array}{l}\text { Pisitioning System) } \\
\text { Garmin }\end{array}$ & Menentukantitikkoordinat \\
\hline 6 & $\begin{array}{l}\text { Kamera Digital } \\
\text { (Sony 1200) }\end{array}$ & Dokumentasi \\
\hline 7 & Kuesioner & $\begin{array}{l}\text { Panduan } \\
\text { dalammewawancarairesponden }\end{array}$ \\
\hline 8 & AplikasiArcGis & Membuat peta \\
\hline
\end{tabular}

\section{Metode Pengambilan Sampel}

Metode pengambilan sampel dalam penelitian ini adalah dengan menggunakan metode Purposive Sampling. Sampel nelayan yang diwawancarai adalah sebanyak 20 responden yang dipilih secara acak. 


\section{Konsep Pengukuran Variabel}

Variabel yang akan diukur dalam penelitian ini adalah:

1. Nilai manfaat langsung yaitu nilai yang dihasilkan dari pemanfaatan secara langsung hutan mangrove yaitu potensi kayu bakar dan penangkapan ikan (Rp/tahun).

2. Nilai manfaat tidak langsung yaitu nilai yang dihasilkan dari pemanfaatan secara tidak langsung hutan mangrove yaitu penahan gelombang (tanggul) (Rp/tahun).

\section{Pengambilan Data Kondisi Ekologi Mangrove}

Untuk pengambilan data kondisi ekologi mangrove dilakukan dengan pembuatan plot. Jumlah plot dalam penelitian ini adalah sembilan plot. Setiap plot memiliki ukuran $10 \times 10 \mathrm{~m}$. Pengambilan data dalam penelitian ini adalah kerapatan jenis, frekwensi jenis, luas area penutupan, dan indeks nilai penting (INP) dari tiap jenis dan luas hutan mangrove.

\section{Indeks Nilai Penting}

Kondisi ekologis hutan mangrove dapat diketahui dengan menggunakan beberapa jenis perhitungan, yaitu kerapatan jenis, frekwensi jenis, luas area penutupan, dan indeks nilai penting (INP) dari tiap jenis. Untuk mencari nilai INP di gunakan tiga perhitungan, yaitu nilai kerapatan tiap jenis, nilai frekwensi tiap jenis, dan nilai dari penutupan tiap jenis, Benu dkk., (2011).

Kerapatan jenis (Di) adalah jumlah tegakan jenis $i$ dalam suatu area. Persamaan untuk mencari kerapatan jenis adalah: $\mathrm{Di}=\mathrm{ni} / \mathrm{A}$
Dimana: $\begin{aligned} & \text { Di }=\text { kerapatan jenis ke } \mathrm{I} ; \mathrm{ni}=\text { jumlah total } \\ & \text { tegakan dari jenis ke I; } \mathrm{A}=\text { luas total area }\end{aligned}$ pengambilan contoh.

Setelah nilai dari kerapatan jenis ini didapat, langkah selanjutnya adalah mencari nilai dari kerapatan relatif jenis (RDi). Kerapatan relatif jenis adalah perbandingan antara jumlah tegakan jenis i (ni) dan jumlah total tegakan seluruh jenis $(\Sigma \mathrm{n})$, dengan persamaan:

$$
\mathrm{RDi}=(\mathrm{ni} / \Sigma \mathrm{n}) \times 100
$$

Penutupan jenis (Ci) adalah luas penutupan jenis i dalam suatu area. Persamaan dari penutupan jenis adalah:

$$
\mathrm{Ci}=\Sigma \mathrm{BA} / \mathrm{A}
$$

Dimana: $\mathrm{BA}=\pi \mathrm{DBH} 2 / \mathrm{A} ;(\pi=3,14) ; \mathrm{DBH}=$ diameter batang pohon jenis kei; $\mathrm{DBH}=\mathrm{CBH} / \pi ; \mathrm{CBH}$ adalah lingkar pohon setinggi dada; $A=$ luas total area pengambilan contoh.

Setelah nilai dari penutupan jenis ini didapat, langkah selanjutnya adalah mencari nilai dari penutupan relatif jenis (RCi). Nilai penutupan relatif jenis adalah perbandingan antara luas area penutupan jenis i (Ci) dan luas total area penutupan untuk seluruh jenis $(\Sigma C)$, dengan persamaan:

$$
\mathrm{RCi}=(\mathrm{Ci} / \Sigma \mathrm{C}) \times 100
$$

Nilai yang terakhir yaitu nilai frekwensi tiap jenis. Frekwensi jenis sendiri merupakan peluang ditemukannya jenis dalam petak contoh/plot yang diamati:

$$
\mathrm{Fi}=\mathrm{Pi} / \Sigma \mathrm{P}
$$

Dimana: $\mathrm{Fi}$ adalah frekwensi jenis $\mathrm{i}, \mathrm{Pi}$ adalah jumlah petak contoh/plot dimana ditemukan jenis i. Sedangkan $P$ adalah jumlah total petak contoh/plot.

Setelah nilainya didapat, selanjutnya adalah menghitung nilai frekwensi relatif jenis yang merupakan perbandingan antara frekwensi jenis i (Fi) dan jumlah frekwensi untuk seluruh jenis $(\Sigma F)$ :

$$
\mathrm{RFi}=(\mathrm{Fi} / \Sigma \mathrm{F}) \times 100
$$

Indeks nilai penting adalah jumlah nilai kerapatan jenis (RDi), frekwensi relatif jenis (RFi), dan penutupan relatif jenis (RCi).

$$
I N P=R D i+R F i+R C i
$$

Nilai penting ini untuk memberikan suatu gambaran mengenai pengaruh atau peranan suatu jenis mangrove dalam ekosistem tersebut.

\section{Analisis Volume Tegakan}

Analisis volume tegakan dilakukan untuk mengetahui besar dari volume kayu mangrove yang ada. Untuk mendapatkan volume kayu, maka harus diketahui terlebih dahulu nilai dari tinggi dan juga keliling lingkaran setinggi dada $(1,3 \mathrm{~m})$ pohon yang menjadi sampel.

Dalam santoso (2005) volume kayu mangrove ini didapat dengan menggunakan persamaan:$$
\mathrm{V}=(\operatorname{Lbd} \times \mathrm{t})
$$

Dimana: $\mathrm{V}=$ Volume; Lbd $=$ luas bidang dasar $\{($ diameter $/ 100) \times 0.5\} 2 \times 3,14 ; \mathrm{T}=$ tinggi $(\mathrm{m}) ; \pi=$ 3,14 .
} 
Analisis volume tegakan yang didapat ini akan menggambarkan kondisi dari hutan mangrove pada tiap hektar. Selain itu juga dapat dijadikan perhitungan awal dari nilai ekonomi potensi kayu mangrove.

\section{Membuat Peta dan Perhitungan Luas Hutan Mangrove}

Sistem Informasi Geografis (Geographic Information Sistem/GIS) yang selanjutnya akan disebut SIG merupakan sistem informasi berbasis komputer yang digunakan untuk mengolah dan menyimpan data atau informasi geografis (Aronoff, 1989). Pembuatan peta dan menghitung luas hutan mangrove yang ada di Desa Lansa dengan menggunakan aplikasi ArcGis, diawali dengan penguduhan gambar dari Google Earth kemudian dilakukan retifikasi untuk menyamakan posisi geografis lokasi penelitian serta melakukan proses digitasi untuk menghitung luas hutan mangrove di Desa Lansa dengan menggunakan kalkulator geometrik yang terdapat di Aplikasi Arcgis.

\section{Perhitungan Nilai Ekonomi Jasa Penyedia Hutan Mangrove}

Untuk mendapatkan nilai ekonomi dari jasa yang di berikan oleh hutan mangrove bagi masyarakat pengguna dilakukan dengan menggunakan metode survei, dengan cara melakukan wawancara secara langsung kepada masyarakat pengguna jasa hutan mangrove dengan menggunakan kuesioner. Kuesioner berisi pertanyaan-pertanyaan mengenai harga/ nilai dari jasa yang didapat. Jumlah responden yang di ambil dalam penelitian ini yaitu 20 orang, terdiri atas 14 orang nelayan dan 6 orang pencari kayu bakar yang di pilih secara acak.

1. Perhitungan nilai ekonomi sumber daya ikan yaitu rata-rata penghasilan nelayan perminggu, dikalikan dengan 4 (jumlah minggu dalam 1 bulan) setelah hasilnya didapat dikalikan lagi dengan 10 bulan (untuk nilai ekonomi ikan dalam 1 tahun) dan dikalikan lagi dengan jumlah kepala keluarga $(\mathrm{KK})$ yang beroperasi menangkap ikan di hutan mangrove.
$\mathrm{NEI}=\mathrm{Pm} \times 4 \times 10 \times \mathrm{Kk}$

Ket: Ne (Nilai ekonomi ikan); Pm (Penghasilan/minggu (507.143)); 4 (Jumlah minggu dalam 1 bulan); 10 (10 bulan); KK (Jumlah kepala keluarga (75)).

2. Perhitungan pemanfaatan kayu bakar dilakukan dengan rata-rata pengambilan kayu bakar per minggu dikalikan dengan jumlah minggu dalam 1 bulan dan dikalikan lagi dengan jumlah bulan dalam 1 tahun. Untuk mendapatkan nilai ekonomi dari kayu bakar didekati dengan mengganti penggunaan kayu bakar dengan tabung gas. Untuk harga pemakaian kayu bakar per minggu setara dengan 1 tabung gas. Nilai ekonomi didapat dengan mengalikan jumlah total pemakaian gas untuk 1 keluarga dalam 1 tahun dengan jumlah total keluarga pemakai gas dan dikalikan lagi dengan harga jual 1 tabung gas. Khusus untuk harga kayu bakar digunakan nilai pengganti dari harga bahan bakar gas (replacement cost). Nilai pengganti bahan bakar gas adalah Rp. 18.000 untuk gas $3 \mathrm{~kg}$.

$$
\mathrm{NE}=\mathrm{Jk} \times \mathrm{Kk} \times \mathrm{Hg}
$$

Ket: NE (Nilai ekonomi); Jk (Jumlah total pemakaian kayu/tahun); Kk (Jumlah kepala keluarga (300)); Hg (Harga 1 tabung gas (Rp 18.000)).

3. Untuk perhitungan nilai ekonomi sebagai penahan gelombang (Tanggul). Menurut data Dinas Pekerjaan Umum Provinsi Sulawesi Utara (2009) untuk membuat bangunan pemecah gelombang diperlukan biaya sebesar Rp 7.086.074 per meter, dan di konversi ke tahun 2018 dengan CPI Inflation calculator menjadi $\mathrm{Rp} 10.900 .000$ per meter.

$\mathrm{NE}=\mathrm{Pt} \times \mathrm{Hpm} / \mathrm{Kb}$

Ket: NE (Nilai ekonomi); Pt (Panjang tanggul (2.370 m)); $\mathrm{Hpm}$ (Harga pembangunan tanggul per meter); Kb (Ketahanan bangunan (10 tahun)).

\section{HASIL DAN PEMBAHASAN}

\section{Gambaran Umum Desa Lansa}

Desa Lansa adalah salah satu Desa di wilayah Kecamatan Wori, Kabupaten Minahasa Utara, Provinsi Sulawesi Utara yang merupakan Desa pesisir dengan topografi datar dan sedikit berbukit dengan ketinggian $100 \mathrm{~m}$ dari permukaan laut dan memiliki luas wilayah kurang lebih $660 \mathrm{Ha}$.

Desa Lansa secara administratif berada di Kecamatan Wori, Kabupaten 
Minahasa Utara. Desa Lansa yang merupakan lokasi penelitian adalah salah satu Desa pesisir yang berbatasan langsung dengan Laut Sulawesi. Dan mempunyai batas administratif Desa dapat kita lihat pada (Tabel 2).

Tabel 2. Letak Administratif.

\begin{tabular}{ll}
\hline Sebelah Utara & Laut Sulawesi \&Desa Lantung \\
\hline Sebelah Timur & $\begin{array}{l}\text { Desa Lantung \& Desa Palaes } \\
\text { Kecamatan Likupang Barat }\end{array}$ \\
\hline Sebelah Selatan & Desa Warisa Kecamatan Talawaan \\
\hline Sebelah Barat & Desa Ponto \\
\hline
\end{tabular}

\section{Kependudukan}

Penduduk Desa Lansa berasal dari suku Sangihe Talaud/Nusa Utara $98 \%$, dan suku lainnya $2 \%$ dengan jumlah 1.428 jiwa yang terdiri dari laki-laki 740 jiwa, perempuan 688 jiwa dan 427 Kepala Keluarga.

Tingkat Pendidikan masyarakat Desa Lansa dari total penduduk sebanyak 1.428 jiwa adalah 23 orang berpendidikan sarjana, 4 orang berpendidikan Diploma, 234 berpendidikan SLTA, 57 Orang belum tamat SLTA/ masih sekolah, 188 orang berpendidikan SLTP, 64 orang belum tamat SLTP/masih sekolah, 13 orang tidak tamat SD, 632 orang berpendidikan SD, 126 orang belum tamat $\mathrm{SD} / \mathrm{masih}$ sekolah, 4 orang tidak sekolah dan 83 orang belum sekolah.

Desa Lansa yang terletak di Kecamatan Wori, Kabupaten Minahasa Utara memiliki sumberdaya hutan mangrove yang cukup luas. Beberapa kelompok masyarakat yang terlibat langsung dalam pemanfaatan ekosistem hutan mangrove diantaranya adalah nelayan, petani, dan pencari kayu bakar.

\section{Hutan Mangrove}

Hutan mangrove yang menjadi objek penelitian adalah hutan mangrove yang terdapat di Desa Lansa yang luasnya kurang lebih 156.10 ha. Selama ini hutan mangrove yang ada hanya dibiarkan saja tanpa adanya pengelolaan.

\section{Kondisi Ekologi Hutan Mangrove}

Berdasarkan hasil penelitian di hutan mangrove Desa Lansa, Kecamatan Wori, Kabupaten Minahasa Utara, jenis mangrove yang ditemukan di lokasi penelitian adalah Rhizophora sp, Avicennia sp, dan Sonneratia sp dengan sedimen hutan mangrove didominasi oleh campuran lumpur dan pasir.

Daerah sepanjang Pesisir Taman Nasional Bunaken Bagian Utara terdapat 6 jenis mangrove (Anthoni dkk., 2017). Kemudian di Daerah Kelurahan Tongkaina Manado terdapat 2 jenis tumbuhan mangrove (Sasauw dkk., 2016). Di daerah hutan mangrove Batuline Desa Bahoi, Kecamatan Likupang Barat, Kabupaten Minahasa Utara terdapat 11 jenis mangrove (Kontu, 2014). Dan di Daerah Distrik Teminabuan, Kabupaten Sorong Selatan juga terdapat 11 jenis mangrove, (Yewen dkk., 2008).

\section{Luas Hutan Mangrove}

Perhitungan luas area hutan mangrove dengan menggunakan aplikasi ArcGis, ditemukan bahwa luas hutan mangrove di Desa Lansa adalah kurang lebih 156,10 hektar (Gambar 2).

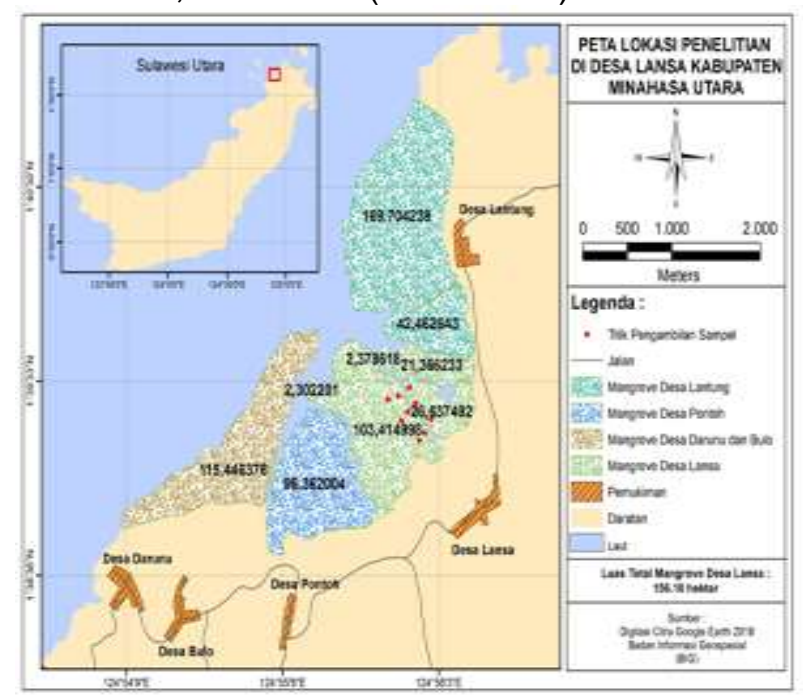

Gambar 2. Luas hutan mangrove.

\section{Indeks Nilai Penting}

Berdasarkan hasil identifikasi dan pengamatan di lokasi penelitian terhadap mangrove yang tumbuh di Desa Lansa dapat di lihat pada (Tabel 3) ditemukan 3 jenis yaitu Rhizophora sp, Avicennia sp, dan Sonneratia sp.

Indeks nilai penting (INP) berkisar antara 0-300 menunjukkan keterwakilan jenis mangrove yang berperan dalam ekosistem sehingga jika indeks nilai Penting 300 berarti suatu jenis mangrove memiliki peran dan pengaruh yang penting dalam komunitas mangrove (Bengen, 
2004). Hasil penelitian yang dilakukan di Desa Lansa didominasi oleh jenis Rhizophora sp, yang ditunjukkan dengan nilai INP yaitu sebesar 179,75 dan diikuti berturut-turut oleh Avicennia sp 73,09 dan Sonneratia sp 47,15.

Kondisi ekologi hutan mangrove di Desa Lansa dilihat dari nilai indeks penting yaitu 179,75 masih baik, dan di dukung oleh Kepmen No 201 tahun 2004 mengenai Kriteria Baku Kerusakan Mangrove, kerapatan lebih dari 1500 pohon/ha dikatakan sangat padat sedangkan kerapatan mangrove yang ada di Desa Lansa 2000 pohon/ha sehingga hutan mangrove di Desa Lansa dikatakan baik.

Tabel 3. Indeks Nilai Penting.

\begin{tabular}{|c|c|c|c|c|c|}
\hline 운 & 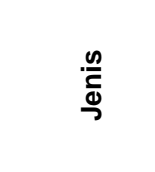 & 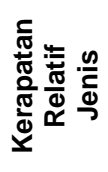 & 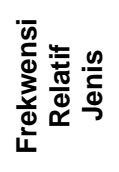 & 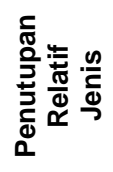 & 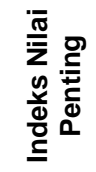 \\
\hline 1 & Rhizopora & 80,11 & 42,86 & 56,78 & 179,75 \\
\hline 2 & Avicenia & 11,93 & 33,33 & 27,83 & 73.09 \\
\hline 3 & Sonneratia & 7,95 & 23,81 & 15,39 & 47.15 \\
\hline
\end{tabular}

\section{Analisis Volume Tegakan}

Analisis volume tegakan digunakan untuk mencari tahu berapa besar dari volume yang dapat dihasilkan kayu mangrove dalam tiap hektarnya. Data ini dapat digunakan untuk mencari nilai manfaat langsung hutan mangrove di lihat berdasarkan potensi kayu yang dapat dihasilkan (Benu dkk., 2011).

Dari hasil pengambilan data diameter batang kayu dan juga tinggi pohon mangrove di Desa Lansa diperoleh hasil potensi volume kayu mangrove sebesar $24.580,57 \mathrm{~m}^{3}$ per ha.

\section{Jasa Ekosistem Hutan Mangrove Desa Lansa}

Hasil wawancara yang di peroleh dari responden mengenai pengetahuan mereka mengenai ekosistem hutan mangrove yaitu mereka mengetahui bahwa mangrove merupakan ekosistem yang dilindungi karena begitu banyak jasa ekosistem yang di berikan, antara lain mangrove sebagai pelindung pantai, tempat berlindung dan mencari makan bagi biota laut yang hidup di hutan mangrove, tempat pencarian ikan bagi nelayan dan kayu bakar
Dalam penelitian ini nilai ekonomi dari jasa ekosistem hutan mangrove di atas yang di ambil hanya 3 yaitu ikan, kayu bakar,danperlindungan pantai. Sebagai informasi, di Pulau Untung Jawa, Kepulauan Seribu, jasa yang disediakan oleh hutan mangrove adalah kayu, buah, ikan, penahan abrasi, tempat mencari makan biota laut, konservasi, edukasi dan pariwisata (Prasetiyo et al., 2016). Hutan mangrove Desa Kulu menyediakan jasa seperti sumberdaya ikan, kepiting, daun nipa, penahan abrasi dan penahan intrusi (Kalitouw 2015). Selanjutnya, hutan mangrove Desa Palaes menyediakan kayu bakar, hasil perikanan, daun nipa, dan penahan abrasi (Benu dkk 2011). Kemudian di Kabupaten Sinjai, Sulawesi Selatan jasa hutan mangrove adalah berupa kayu bakar, bahan bangunan, buah bakau, dan daun bakau (Saprudin dan Halidah, 2012).

Tabel 4. Nilai Ekonomi Jasa Ekosistem Mangrove.

\begin{tabular}{clr}
\hline No & Ketegori Manfaat & Nilai Manfaat/Tahun \\
\hline 1 & Ikan & $\operatorname{Rp~1.521.429.000~}$ \\
2 & Kayu bakar & $R p ~ 259.200 .000$ \\
3 & Tanggul & $R p 2.583 .300 .000$ \\
\hline & Total & Rp4.363.929.000 \\
\hline
\end{tabular}

Berdasarkan hasil penelitian dengan masyarakat mengenai informasi jasa ekosistem hutan mangrove dapat di lihat pada (Tabel 5) bahwa nilai pemanfaatan di hutan mangrove yang terbesar adalah sebagai penahan gelombang (Tanggul) dengan nilai sebesar $\operatorname{Rp} \operatorname{Rp} 2.583 .300 .000$ dengan panjang tanggul 2.370mdengan ketahanan selama 10 tahun. Nilai ini didapat dengan cara mengalikan biaya pembangunan tanggul per meter dikalikan dengan Panjang tanggul dan di bagi dengan ketahanan tanggul selama 10 tahun.

Nilai pemanfaatan ikan dari para nelayan sebesar $R p$ 1.521.429.000 per tahun, Penangkapan ikan dilakukan dengan menggunakan alat berupa pancing dan jaring. Nilai ini didapat dari rata - rata penghasilan nelayan/minggu dikalikan dengan 4 (jumlah minggu dalam 1 bulan) dan dikalikan lagi dengan 10 bulan, setelah hasilnya didapat dikalikan lagi dengan jumlah KK yang menangkap ikan di mangrove. 
Nilai pemanfaatan sebagai kayu bakar yaitu Rp 259.200.000 juta/tahun, Pengambilan kayu bakar dilakukan oleh masyarakat adalah kayu-kayu kering yang terdapat pada hutan mangrove dalam 1 minggu masyarakat dapat menghasilkan 20 ikat kayu bakar/KK berarti dalam setahun masyarakat dapat menghasilkan 960 ikat kayu bakar.

Nilai ekonomi total jasa penyedia hutan mangrove Desa Lansa adalah $\mathrm{Rp}$ 4.363.929.000/tahun. Sebagai perbandingannya yaitu nilai ekonomi jasa ekosistem hutan mangrove Pulau Untung Jawa, Kepulauan Seribu adalah Rp. 7.895.726.912, (Prasetiyo et al., 2016). Desa Palaes memiliki total nilai ekonomi ekosistem hutan mangrove sebesar $\mathrm{Rp}$ 10.888.218.123 (Benu dkk., 2011). Selanjutnya, Desa Kulu memiliki nilai ekonomi sebesar Rp 2.316.961.823, (Kalitouw, 2015). Kemudian untuk Kabupaten Sinjai, Sulawesi Selatan yaitu 2503.75, (Saprudin dan Halidah, 2012).

\section{KESIMPULAN DAN SARAN}

\section{Kesimpulan}

1. Jasa ekosistem yang disediakan oleh hutan mangrove bagi masyarakat Desa Lansa yaitu Mangrove Regulation Service, mangrove provisioning service dan mangrove cultural services.

2. Untuk kondisi ekologi hutan mangrove di Desa Lansa di katakana baik karena memiliki nilai kerapatan mangrove 2000 pohon/ha dan didapat nilai kerapatan relatif jenis yang tertinggi yaitu Rhizophora sebesar $80,11 \%$ dan diikuti oleh Avicennia sp $11,93 \%$ dan Sonneratia sp 7,95\%. untuk nilai frekwensi relatif jenis Rhizophora $\mathrm{sp}$ memiliki nilai tertinggi yaitu $42,86 \%$ dan diikuti oleh Avicennia 33,33\% dan Sonneratia sp 23,81\%. Dan untuk nilai penutupan relatif jenis Rhizophora $\mathrm{sp}$ memiliki nilai tertinggi yaitu $56,78 \%$, Avicennia sp 27,83\% dan Sonneratia sp $15,39 \%$. Sehingga didapat nilai INP yang tertinggi yaitu Rhizophora $\mathrm{sp}$ 179,75 dan diikuti berturut-turut oleh Avicennia sp 73,09 dan Sonneratia $s p$ 47,15 .

3. Nilai ekonomi jasa ekosistem hutan mangrove Desa Lansa sebagai pelindung pantai adalah $\mathrm{Rp}$ 2.583.300.000, sumberdaya ikan $R p$ 1.521.429.000, sumber kayu bakar $R p$ 259.200.000 juta/tahun. Total nilai ekonomi jasa ekosistem hutan mangrove adalah $\mathrm{Rp} \mathrm{4.363.929.000/}$ tahun.

\section{Saran}

1. Mengingat masih kurangnya penelitian mengenai kondisi ekologi dan nilai jasa penyedia ekosistem mangrove. Maka masih perlu diadakan penelitianpenelitian selanjutnya pada tempat atau wilayah lain, khususnya di Sulawesi Utara.

2. Perlu diadakan sosialisasi ke masyarakat mengenai manfaat dan jasa yang di berikan ekosistem mangrove bagi masyarakat.

\section{DAFTAR PUSTAKA}

Anthoni, A., J.N.M. Schaduw., C.F.A. Sondak. 2017. Persentase Tutupan Dan Struktur Komunitas Mangrove Di Sepanjang Pesisir Taman Nasional Bunaken Bagian Utara. Jurnal Pesisir dan Laut Tropis. Vol. 2 No. 1. 13-21

Aronoff, Stan. 1989 Geographic Information System; A Management Perspective, Ottawa. WDL, Publications

Bengen, D.G. 2004. Pedoman Teknis Pengenalan dan Pengelolaan Ekosistem Mangrove. PKSPLIPB. Bogor.

Benu, S.O.L., J. Timban., R Kaunang., F Ahmad., 2011. Valuasi Ekonomi Sumberdaya Hutan Mangrove di Desa Palaes Kecamatan Likupang Barat Kabupaten Minahasa Utara. ASE. Vol. 7. No. 2. 29-38.

Hein, Lars, Kris van Koppen, Rudolf S. de Groot, Ekko C. van lerland. 2006. Spatial scales, stakeholders and the valuation of ecosystem services, Ecological Economics 57 (2006) 209228.

Kalitouw W.D., 2015. Potensi Ekonomi Ekosistem Hutan Mangrove di Desa Kulu Kecamatan Wori Kabupaten Minahasa Utara. Tesis: Program Pascasarjana IPB. Bogor..

Kontu, T. 2014. Struktur Komunitas Mangrove Batuline Desa Bahoi Kecamatan Likupang Barat Kabupaten Minahasa Utara. Jurnal Pesisir dan Laut Tropis. Vol. I No. (1) : 24-29.

Prasetyo, L.B. T. Supartono, A.P Kartono, A. Hikmat \& S. Ramdhoni. 2016. Habitat Suitability Index (HSI) Surili (Presbytis comate Desmarest, 1822) in mixed forest of Kuningan District, West JavaIndonesia. IOP Conference series: Earth and Environmental Science, Volume 54.

Santoso. 2005. Valuasi Ekonomi Ekosistem Hutan Mangrove di Kawasan Pondok Bali, Desa 
Legonwetan, Kecamatan Legonkulon, Kabupaten Subang, Jawa Barat. Bogor. Institut Pertanian Bogor.

Saprudin, dan Halidah, 2012. Potensi dan Nilai Manfaat Jasa Lingkungan Hutan Mangrove di Kabupaten Sinjai, Sulawesi Selatan. Jurnal Penelitian Hutan dan Konservasi Alam, 9(3):213219.

Sasauw, J., J.D. Kusen., J.N.W. Schaduw., 2016. Struktur Komunitas Mangrove di Kelurahan
Tongkaina Manado. Jurnal Pesisir dan Laut Tropis. Vol. 2. No. 1.

Yewen, M., Mudjirahayu., T.F. Pattiasina., Bawole. $R$, 2008. Struktur Komunitas dan Penyebaran Mangrove Serta Upaya Pengelolaannya Oleh Masyarakat Distrik Teminabuan, Kabupaten Sorong Selatan. Departemen Kelautan dan Perikanan Indonesia, Hal. 305-319. 